\title{
Research on the Integration of Quality Education and Innovation and Entrepreneurship Education in Universities of Science and Engineering in China
}

\author{
Chang Chengxia \\ School of Foreign Language Studies, Henan Polytechnic University, Jiaozuo, China
}

Email address:

hpuccx@163.com

\section{To cite this article:}

Chang Chengxia. Research on the Integration of Quality Education and Innovation and Entrepreneurship Education in Universities of Science and Engineering in China. Teacher Education and Curriculum Studies. Vol. 3, No. 1, 2018, pp. 6-9. doi: 10.11648/j.tecs.20180301.12

Received: March 5, 2018; Accepted: March 26, 2018; Published: April 26, 2018

\begin{abstract}
In the knowledge era, innovation and entrepreneurship education, which is the core content of quality education, is a key education for college students in science and engineering universities. And it is the requirement of China to cultivate comprehensive high-quality talents. The practical way of high-quality entrepreneurship and employment, and the education of innovation and entrepreneurship are imminent. Researchers from different disciplines have studied the innovation and entrepreneurship education from different perspectives in China but the research time is relatively short. Moreover, there are not many researches on the innovation and entrepreneurship education system in science and engineering universities, and the integration of innovation and entrepreneurship education and quality education research is very few people interested. This paper aims to explore the meaning and the mode of the effective integration mode.
\end{abstract}

Keywords: Innovation and Entrepreneurship Education, Quality Education, The Integration Mode

\section{Introduction}

Innovation and entrepreneurship have a very important mission and value in the context of the new normalcy of the Chinese economy. General Secretary Xi Jinping emphasized that "Innovation is always an important force for promoting the development of a country and a nation. As a big developing country, China must innovate implementation of development strategy." The establishment of an innovative nation with mass entrepreneurship and innovation has set new tasks and requirements for personnel training in Chinese higher education institutions. However, at present, the system of innovation and entrepreneurship education in colleges and universities in China is still not competent for this task. Therefore, it is still necessary to construct a scientific, comprehensive and systematic education system for innovation and entrepreneurship, to break up the current system of innovation and entrepreneurship education that is scattered, single-handed and ineffective.

High quality is the key to the success of innovation and entrepreneurship. Therefore, innovation and entrepreneurship education and quality education has an inherent coupling. For a long time, colleges and universities in China actively explore the basic methods and practice of quality education, and have accumulated rich theoretical and practical experience. Through integrating quality education into innovative and entrepreneurial education, and expanding the channel of quality education by innovation and entrepreneurship education, both quality education and innovation and entrepreneurship education can be complemented.

Universities of science and engineering in China are major battlefields for cultivating high-quality innovative entrepreneurship and shouldering the responsibility of fostering innovative entrepreneurship capable of better serving the national and local economic construction.

\section{The Necessity and Meaning for Integrating Quality Education into Innovation and Entrepreneurship Education}

As one of the hot issues, the innovation and entrepreneurship education in colleges and universities has 
attracted the attention of more and more experts and scholars in China. As of June 21, 2017, there were 6,015 articles on the topic of "Innovation and Entrepreneurship Education", the earliest literature appeared in 1999 and nearly 20 years ago. As can be seen from the existing achievements, it mainly includes research on the connotation, mode, problems and path of innovation and entrepreneurship education in higher education institutions. As a result, there are more and more high-quality achievements.

Many science and engineering universities in China also have problems in innovation and entrepreneurship education. Scholars generally believe that innovation and entrepreneurship education in science and engineering universities has such problems as low awareness of innovation, imperfect curriculum system, insufficient practical platform and weak faculty.

Some Chinese scholars put forward the countermeasures and ways to improve the innovation and entrepreneurship education in science and engineering colleges and improve the ability of innovation and entrepreneurship of science and engineering college students.

Meanwhile, some scholars try to build a system of innovation and entrepreneurship education in universities of science and technology by establishing a correct concept of innovation and entrepreneurship education, enriching its forms, promoting the integration of innovation and entrepreneurship education and professional education, and strengthening the construction of teachers' ranks for innovation and entrepreneurship education system.

However, due to the late start of innovation and entrepreneurship education in China, the pursuit of scale efficiency is higher than the pursuit of quality under the background of the popularization of higher education, and the vision of research is limited.

It is of great practical significance to carry out the reform of innovation and entrepreneurship education and the deepening of quality education in colleges and universities in China. Mass entrepreneurship and innovation are the way to enrich the people and strengthen the nation. As the main carrier of innovation and entrepreneurship education, colleges and universities bear the important mission of training and conveying a large number of innovative and entrepreneurial talents for the society.

In 2015, the State Council issued The Opinions on Deepening the Innovation and Entrepreneurship Education Reform in Higher Education Institutions. According to the document, from 2015 onwards, it is necessary to deepen the education reform and innovation and entrepreneurship, and to popularize the education for innovation and entrepreneurship in 2017 , to 2020 to establish a complete set of university innovation and entrepreneurship education system.

Promoting innovation and pioneering education is not only the need of building an innovation-oriented society, but also the inevitable choice for the development of colleges and universities. As an important front for educating qualified builders and reliable successors, colleges and universities must advance with the times and use innovation and entrepreneurship education and quality education to broaden employment direction of college students, relieve the pressure of employment, and cultivate high-quality talents with innovative spirit and practical ability for building an innovative country.

\section{The Integration Mode for Quality Education into Innovation and Entrepreneurship Education}

Innovation and entrepreneurship education and quality education has an inherent coupling. In the era of knowledge economy, colleges and universities must carry out quality education throughout the comprehensive reform of higher education from beginning to end, establish the college students' innovative spirit and entrepreneurial awareness as important tasks to improve the quality of personnel training, and earnestly deepen the innovation and entrepreneurship education reform in colleges and universities.

In the specific implementation process, colleges and universities in China should apply the concept of quality education to guide college students' entrepreneurship education. At the same time, colleges and universities should start with the entrepreneurship education of college students, and promote the in-depth implementation of quality education. The cultivation of all kinds of qualities of college students is ultimately the cultivation of basic qualities of all kinds of entrepreneurship, and ultimately the unification of individual value and social value of college students, and the goal of all-round development of human beings. This is also the ultimate goal of quality education.

\section{1. "Fusion" Training}

"Fusion" training, that is, the concept of integration, process integration, evaluation integration. Concept integration refers to the integration of quality education and innovative entrepreneurship education through the talent training program, integrating into the curriculum system, and permeating the practice link. Process integration refers to the organic unity of quality education and innovation and entrepreneurship education in the whole process of education and teaching. It is the core element of quality education and innovation and entrepreneurship in the process of education and teaching. Evaluation fusion is the integration and evaluation of students' quality evaluation system and innovation and entrepreneurship, so that students should not only focus on quality improvement, but also emphasize the cultivation of innovation and entrepreneurship.

\section{2. "Stratification" Implementation}

"Stratification" implementation, namely, the implementation of the integration of three levels of development. One is to open the curriculum of integrated innovation and entrepreneurship to improve the consciousness of innovation and entrepreneurship in an all-round way. 
Researchers need to explore the integrated curriculum system of quality education and innovation and entrepreneurship education through the combination of cognitive experience and scene experience of experiential teaching, behavioral operations and simulation operations. Researchers and teachers in Chinese universities are also encouraged to systematically cultivate students' innovation and entrepreneurship ideology, literacy and professional knowledge to enhance innovation and entrepreneurship interest, improve the overall quality of students, consolidate the ideological foundation of innovation and entrepreneurship.

The second way is to cultivate fusion innovation and entrepreneurship team. It will make full use of resources of government, society, enterprises, alumni, friends of the school to build the four mechanisms including motivation mechanism, incentive mechanism, guarantee mechanism and coordination mechanism. Talent pooling, platform building, project cooperation, strategic alliances and the like to encourage and set up innovative business groups, including various types of science and technology organizations, entrepreneurship teams, to give venues, capital and technical support. By participating in scientific and technological activities, the spirit of innovation can be stimulated, the quality and ability of practice can be improved, and the practical basis of innovation and entrepreneurship can be consolidated.

Third, improve the integrated innovation and entrepreneurship platform, focusing on incubating the seeds of innovation and entrepreneurship. Through establishing an innovation and entrepreneurship college, setting up a platform for innovation and entrepreneurship and establishing a four-support system of "professional support, legal support, social support and emotional support", professional services and guidance on innovation and entrepreneurship can be provided for innovative and entrepreneurial high-quality teams and individuals. Moreover, the local governments, universities and companies can make joint efforts to provide the practice innovation place and display platform, the training in front of potential incubators and entrepreneurs incubators to promote the transformation of practice.

\section{Further Discussion}

Innovation and entrepreneurship has become an important strategy in China's modernization. The students of science and engineering master the professional theory and skills, which are the backbone of the modernization construction, and the university has the responsibility to strengthen the innovation in the training of talents.

The time of research on innovation and entrepreneurship education is relatively short in China. There are not many researches on innovation and entrepreneurship education system in science and engineering universities, and few studies have been done about the integration mode. This aspect restricts the development of the research, on the other hand, it provides a broad space for the related research. The innovation of this study is as follows:

First, it puts forward the innovation and entrepreneurship education mode that integrates innovation and entrepreneurship education and quality education. The research will be helpful to change the educational mode of the single development and independent training of the innovation and entrepreneurship education.

Second, it puts forward the operation mechanism and practice path of "integrated and stratified" innovation and entrepreneurship education in universities of science and engineering. This study explores the effective integration mode of quality education and innovation and entrepreneurship education, puts forward the construction of "integrated hierarchical" innovation and entrepreneurship education operation mechanism, to carry out the combination of theory and practice both inside and outside the class through the school innovation and entrepreneurship. The path of education practice can effectively make up for the lack of innovation and entrepreneurship education in some science and engineering colleges and universities.

\section{Acknowledgements}

"This research was supported by Higher Education Teaching Reform Research and Practice Project in the Educational Department of Henan Province(2017-251); Humanities and Social Sciences Foundation Project in the Educational Department of Henan Province (2017-ZZGH-196); The 12th Five-years Plan of Henan Science of Education (2015-JKGHYB-0064). "

\section{References}

[1] LIN Yu-liang \& ZENG Chen. (2016). Analysis and Construction of Innovation and Entrepreneurship Education in Universities. Heilongjiang Researches on Higher Education, 265(5):108-110.

[2] LIN Wei-hua. (2015). A Research on Entrepreneurship and Innovation Education for University Students Guided by the Theory of "China Dream". Journal of Jilin Teachers Institute of Engineering and Technology, 31(9):18-20.

[3] XU Chang. (2016). On Integration Path of Innovation and Entrepreneurship Education with Professional Quality Education. Journal of Jilin Teachers Institute of Engineering and Technology, 31(9):20-22.

[4] XU Wei-ping. (2016). Research on the Education of Entrepreneurship and Innovation in China: from the Prospective of Document Analysis. Journal of Changzhou Vocational College of Information Technology, 15(2):88-95.

[5] YANG Ji-chun. (2016). A Study on the Problems and Response Strategies in College Students' Entrepreneurship Education. Journal of Northeast Normal University, 35(1):179-182.

[6] YU Wen-xiang. (2016). Research on the College Innovative Education and innovative Quality. Journal of Tianjin Vocational Institutes, 18(2):37-40.

[7] ZHANG Guo-hua. (2016). New Ways of Students' Innovative Entrepreneurship Education in Universities. Education Teaching Forum, 48(11):221-222. 
[8] ZHANG Qi-xiang. (2017). On China's New Entrepreneurship Education Frame with the Policy Backgrounds of Popular Entrepreneurship and Innovation. Journal of Jilin Teachers Institute of Engineering and Technology, 38(3):140-146.

[9] ZHAO Xiang-jun \& ZHOU Ying. (2016). On College Students'
Quality Education. Journal of Heilongiiang College of Education, 35(5):10-12.

[10] ZHOU Jian-song \& ZOU Hong-qiu. (2015). Responsibility and Strategies of the Quality Education in Universities. Research in Higher Education of Engineering, 6(1):125-129. 